\title{
Estimation of Soil Erosion Using RUSLE Model and GIS: The Case of Satinskyi Catchment, Western Rwanda
}

Byizigiro, R. V. ${ }^{1}$, Rwanyiziri, G. ${ }^{2,3}$, Mugabowindek we, M. ${ }^{3}$, Kagoyire, C. ${ }^{3}$, Biryabarema, $\mathbf{M}^{4}$

1. Division of Geography, College of Education, University of Rwanda, Rukara Campus. P.O. Box: 55 Kayonza, Rwanda

2. Department of Geography and Urban Planning, College of Science and Technology, University of Rw anda, Nyarugenge Campus. P.O. Box: 3900 Kigali, Rwanda

3. Centre for Geographic Information Systems and Remote Sensing (CGIS), College of Science and Technology, University of Rwanda, Nyarugenge Campus. P.O. Box: 3900 Kigali, Rwanda

4. School of Mining and Geology, College of Science and Technology, University of Rwanda, Nyarugenge Campus. P.O. Box: 3900 Kigali, Rwanda

Correspondence: Rutazuyaza Vaillant Byizigiro, Email: byizigiro.vaillant@gmail.com

\begin{abstract}
The problem of soil erosion in Rwanda has been highlighted in previous studies. They have shown that half of the country's farmland suffers moderate to severe erosion, with the highest soil loss rates found in the steeper and highly rainy northern and western highlands of the country. The purpose of this study was to estimate soil loss in Satinskyi, one of the catchments located in Ngororero District of Western Rwanda. This has been achieved using the Revised Universal Soil Loss Equation (RUSLE) model, which has been implemented in a Geographic Information Systems (GIS) environment. The methods consisted of preparing a set of input factor layers including Slope Length and Steepness (LS) factor, Rainfall Erosivity (R) factor, Soil Erodibility (K) factor, Support Practice (P) factor, and Land Surface Cover Management Factor (C) factor, for the model. The input factors have been integrated for soil loss estimates computation using RUSLE model, and this has enabled to quantitatively assess variations in the mean of the total estimated soil loss per annum in relation to topography and land-use patterns of the studied catchment. The findings showed that the average soil loss in Satinskyi catchment is estimated at $38.4 \mathrm{t} / \mathrm{ha} /$ year. It was however found that about $91 \%$ of the study area consists of areas with slope angle exceeding $15^{\circ}$, a situation which exposes the land to severe soil loss rates ranging between $31 \mathrm{t} / \mathrm{ha} /$ year and $41 \mathrm{t} / \mathrm{ha} /$ year. Apart from the steep slope, changes in land use also contribute to high rates of soil loss in the catchment.
\end{abstract}

Keywords: Soil Erosion Estimation, GIS, RUSLE, Satinskyi Catchment, Rwanda

\section{Introduction}

Previous studies have highlighted adverse impacts of widespread soil erosion which include soil degradation, water siltation, reduced agriculture production among others (Montgomery, 2007; Karamage et al., 2016; Ashras \& Issaka, 2017), all known to compromise human sustainability. Anthropogenic activities such as ploughing, man's search for mineral resources, and other human activities such as constructions, impact on land use and land cover are 
considered to be among the aggravating factors interplaying with natural factors to determine the rates of soil erosion in a given area (Zhao and Hou, 2019). The main natural factors of soil erosion include topography, rainfall, soil properties, and general land management. Estimation of soil loss is however often difficult due to the complex nature of interconnectivity and interdependency between the status of the human and the biophysical parameters (Gurebiyaw et al., 2018). In this regard, researchers have put forward a range of models for estimating soil erosion rates.

Many computer-based models have been developed to explore soil erosion at the catchment scale. Merritt et al. (2003) have reviewed some of them and showed observed great differences of these models in terms of the scale of application, complexity, required inputs for model calibration, represented processes, and the types of final outputs (Renard et al., 1997; Merritt et al. 2003).

Some of the widely used models in soil loss estimation include Water Erosion Prediction Project Model (WEPP), European Soil Erosion Model (EUROSEM), Griffith University Erosion System Template (GUEST), Soil and Water Assessment Tool (SWAT), Universal Soil Loss Equation (USLE), and Revised Universal Soil Loss Equation (RUSLE), among others.

Water Erosion Prediction Project (WEPP) is a physically-based model, incorporating the fundamentals of hydrology, soil physics, plant science, hydraulics, and erosion mechanics (Flanagan et al. 2001). It reflects the effects of soil surface conditions due to agricultural, range and forestry practices on storm runoff and erosion, but does not consider erosion, transport and deposition processes in permanent channels, such as classical gullies and perennial streams (Merritt et al. 2003).

The European Soil Erosion Model (EUROSEM) is a dynamic distributed model for simulating erosion, transport, and deposition of sediment over the land surface by interrill and rill processes (Morgan etal. 1998). It is designed as an event-based model for both individual fields and small catchments. Model outputs include total runoff, total soil loss, the storm hydrograph, and the storm sediment graph. However, the model doesn't apply for larger catchments and is unable to generate rills and gullies from an unrilled overland flow plane and doesn't account for storm soil surface dynamics (Favis-Mortlock et al., 2001).

GUEST (Griffith University Erosion System Template) was designed to interpret temporal fluctuation in sediment concentration for varying slopes, and from bare soil in single erosion events (Rose et al. 1998). It incorporates the simultaneous effects of rainfall and runoff and of deposition on sediment concentration. Although it great usefulness, GUEST is a complex process-based model and consequently has a reasonably large data requirement. Required data include among many other detailed surveys of the pilot site, such as the frequency and geometry of rills before modelling (Rose et al. 1998).

The Soil and Water Assessment Tool (SWAT) is a physically GIS-based distributed hydrological model that uses multi-criteria evaluation (MCE) (Setegn et al. 2009). It allows for the discretisation of a watershed by dividing it into multiple sub-watersheds, which can then be further sub-divided into hydrologic response units (HRUs) that consist of homogeneous land 
use, management, and soil characteristics (Setegn et al. 2009). The model, through the two phases (land and stream routing), simulates the routines for evapotranspiration, surface runoff, infiltration, percolation, return flow, groundwater flow, channel transmission losses, channel routing, and plant water use processes among others. However, researchers have noted some limitations of the model including but not limited to formulas, which are empirical, limitation in the representation of erosion and sediment transport, and the no-applicability for $2 \mathrm{D}$ or $3 \mathrm{D}$ hydraulics applications (Grey et al. 2014).

The Revised Universal Soil Loss Equation (RUSLE) model used in this study is an improved version of USLE model (Wischmeier \& Smith, 1978), which has broadened its application to different situations, including forest, rangeland, and disturbed lands such as mining areas (Zhang et al., 2016; Renard et al. 1997). When using the RUSLE, the effects of topography on soil erosion are estimated by the slope length (L) and slope steepness (S) constituents of the dimensionless $\boldsymbol{L S}$ factor, where LS is one of five component factors including Support Practice Factor $(\boldsymbol{P})$, Rainfall Erosivity Factor $(\boldsymbol{R})$, Soil Erodibility Factor $(\boldsymbol{K})$, and Land Surface Cover Management Factor $(\boldsymbol{C})$.

Previous studies that applied the RUSLE model to study soil erosion in Rwanda have found that half of the country's agricultural land is affected by soil erosion (MoE, 2018; Karamage et al., 2016, Nyesheja et al. 2019). The combination of steep hillsides, rain-fed small-scale agriculture, as well as high precipitations, leads to very high soil erosion rates in different parts of the country (REMA, 2015). The highly elevated and mountainous areas in the northern and western parts of the country, in which Satinskyi catchment is located, are highly exposed to the soil erosion and its effects, given the dominance of high inclination of slopes and heavy rainfall patterns (Rwanyiziri et al., 2019; RoR, 2018; Karamage et al. 2016).

A limited number of previous studies have used the RUSLE model to assess soil erosion in Rwanda. Some of them have assessed soil erosion countrywide and few studies have limited to local scales. Byizigiro (2016), Shao et al. (2016), and Zhang et al. (2016) evaluated soil erosion at local scale; He al. (2020) evaluated soil erosion countrywide. The topographic and Land Use factors were found to have an important role in the amount of soils eroded in Rwanda. Depending on the scale of research, rates of soil erosion vary and stay in reasonably same ranges, but far exceed the recommended tolerable soil loss accepted for maintaining crop productivity.

Nevertheless, RUSLE model has a number of weaknesses such as not being event responsive, ignoring the processes of rainfall-runoff, and how these processes affect erosion, as well as the heterogeneities in inputs such as vegetation cover and soil types. Given the fact that the model is not event-based, gully erosion and mass movement are ignored and the deposition of sediment is not considered to occur in the modelled area. This study will serve as a tool for territorial planning and decision-making as it points out the merits and limitations of some territorial management actions.

Satinskyi catchment, located in Ngororero District of Western Province, is one of the areas highly affected by soil erosion in Rwanda, where agriculture and mining constitute the economic activities for the majority of the population. In this region, natural conditions such 
as steep topography $\left(>26^{\circ}\right)$, high annual precipitation $(1090-1597 \mathrm{~mm})$, and human impacts have made the area prone to intensive soil loss (Byizigiro et al., 2015).

\section{Mate rials and Methods}

\subsection{Study Area Description}

Satinskyi Catchment is located in Ngororero district, one of the seven districts making up the Western Province of Rwanda. The spatial location of the study area is bounded by $1^{\circ} 44^{\prime} 00^{\prime \prime}$ and $1^{\circ} 60^{\prime} 00^{\prime \prime}$ South Latitude and 29 $27^{\prime} 0^{\prime \prime}$ ' and 29 40'0" of East Longitude. The area is deeply dissected by Satinskyi River and its tributaries, namely Muhembe, Gaseke, Rutemba, Mugogwe, Nyamahura, and Kazaba (Figure 1). It falls within a temperate climate with an annual average temperature of $18^{\circ} \mathrm{C}$ as a consequence of its high altitude ranging between 1401 and $2843 \mathrm{~m}$, in spite of its equatorial latitude (Ngororero District, 2013). High annual precipitation (ranging between $1091 \mathrm{~mm}$ and $1597 \mathrm{~mm}$ ) and a generally steep topography (> $26^{\circ}$ ) constitute the major natural factors influencing the geomorphological processes in the area, which are aggravated by agriculture and mining operations that contribute to increased soil erosion rates observed in the area. Mining has caused environmental damages in different mining sites and has exacerbated the problem of soil erosion in the Satinskyi catchment (Ngororero District, 2013).

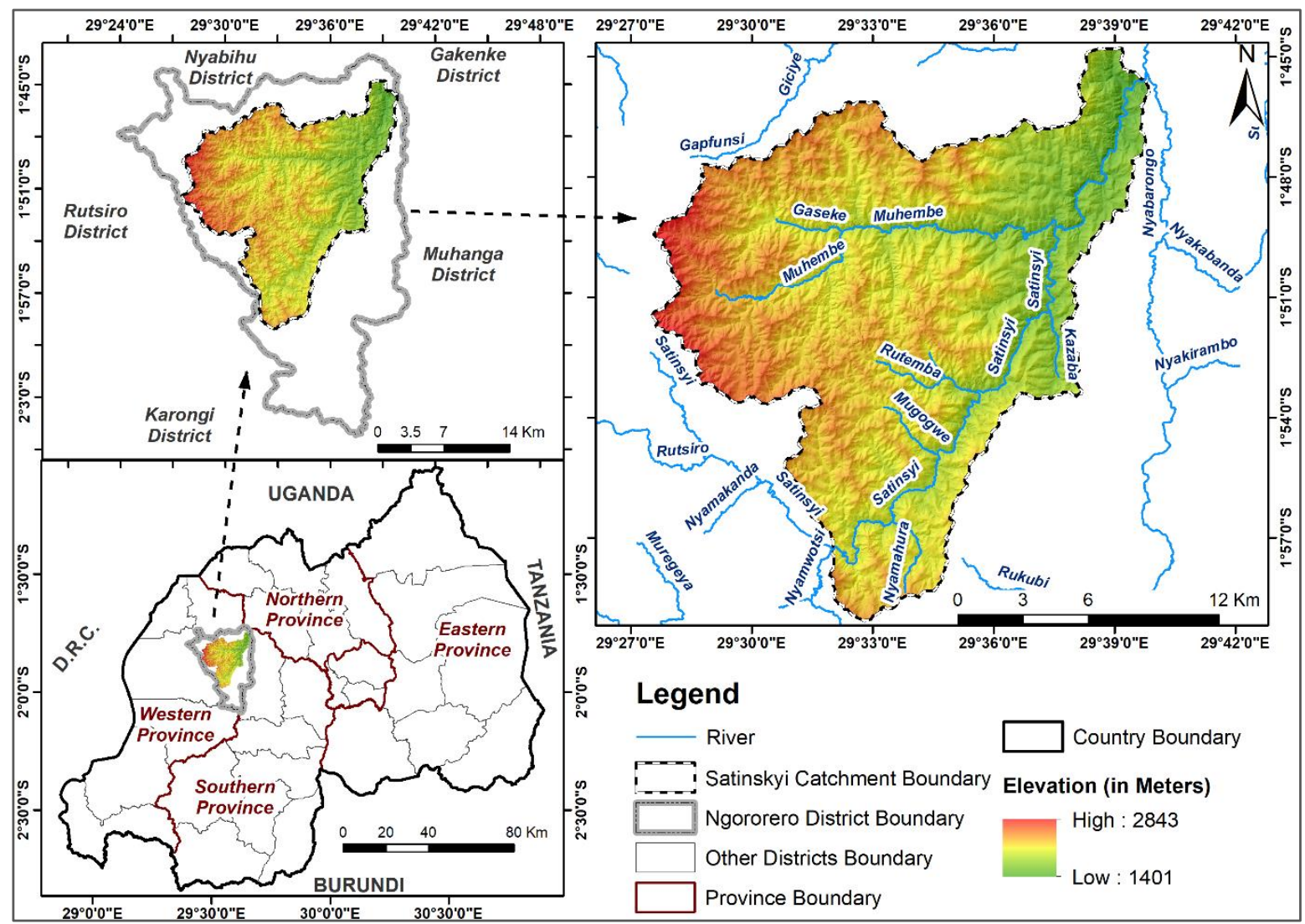

Figure 1: Location Map of Satinskyi Catchment 


\subsection{Research Data}

The processed input factors in a GIS environment enabled the obtaining of the five factors: LS, $\mathrm{R}, \mathrm{P}, \mathrm{K}$, and $\mathrm{C}$, required for the RUSLE model. Land Use and Land Cover (LULC) data produced from Landsat 8 OLI time series, enabled us to produce the land cover Management Factor (C); while daily recorded rainfall data at various stations countrywide from 1950 up to 2018 (provided by Rwanda Meteorological Agency - RMA) enabled to determine the Rainfall Erosivity Factor (R). At the same time, the existing $10 \mathrm{~m}$ DEM was processed to generate the topographic Factor (LS). The slopes were reclassified to allocate them corresponding indices to produce the Support Practice or (Conservation) Factor (P) after Shin (1999). Finally, the Soil Erodibility Factor $(\mathrm{F})$ was generated based on the soil data accessed through the Vital Signs Project (http://www.vitalsigns.org) which is a soil database project implemented in different African countries including Rwanda, by Conservation International (CI) through Wildlife Conservation Society (WCS) (WCS, 2019). The project has followed the methodology used in Tropical Ecology Assessment and Monitoring (TEAM), Africa Soil Information System (AfSIS) which draws on Land degradation Surveillance Framework (LDSF) and Living Standards Measurement Study (LSMS) during its soil sample collection and analysis (2015 2019) (Vågen et al. 2013). The following flowchart (Figure 2) captures the input data used, the GIS-RUSLE processing workflow, and derived outputs.

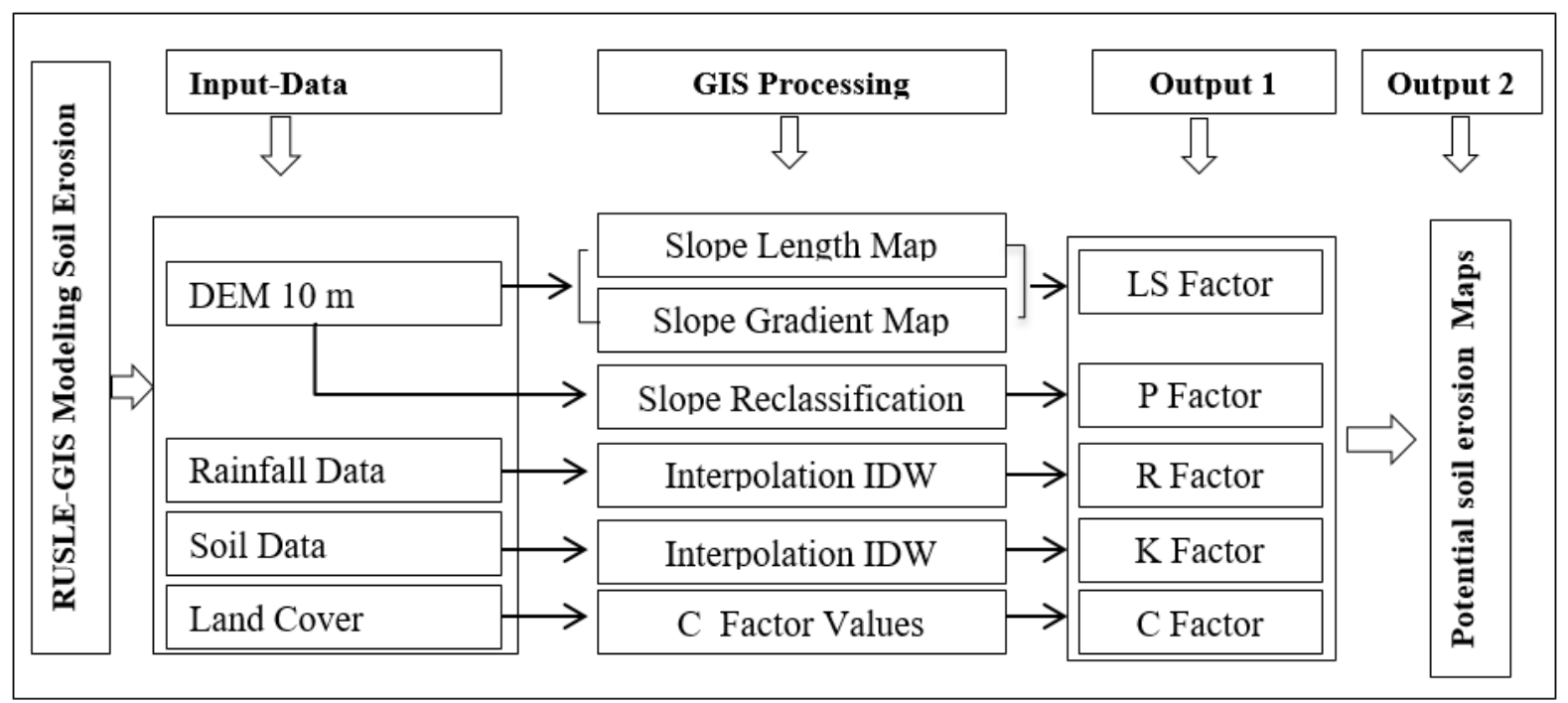

Figure 2: Flowchart showing RUSLE-GIS Workflow

$$
\mathrm{A}=\mathrm{LS} \times \mathrm{P} \times \mathrm{R} \times \mathrm{K} \times \mathrm{C}
$$

A (ton/ ha/year): Spatial Average of Annual Total Soil Loss,

LS (dimensionless): Topographic Factor (Slope Length and Steepness)

P (dimensionless): Support Practice Factor (Soil Conservation Methods)

R (MJ mm /ha/hr/year)): Rainfall and Runoff Erosivity Factor

K (t. h/ MJ/mm/)): Soil Erodibility Factor

C (dimensionless): Land Surface Cover Management Factor 


\subsection{Research Methods}

Data and their related attributes required for the model were input into the GIS by manual digitization and keyboard entry. The polygons and their attributes were connected with a uniform code. The obtained vector maps were later converted into raster, which had the same reference system and resolution as the $10 \mathrm{~m}$ resolution DEM. The data sources were integrated into ArcGIS with a grid-cell format. Each defined cell (pixel) had an exact location in space, determined by the grid orientation, cell size, and a list of assigned attributes. The area-weighted mean of the potential erosion rates for the study area was computed using a zonal statistics tool. Details on data and processing methods are provided under respective RUSLE Factors in the next section.

\section{a) Topographic Factor (LS)}

Topographic Factor, also referred to as Slope Length and Steepness Factor (LS), reflects the effect of topography on soil erosion. An increasing slope gradient and slope length cause higher overland flow velocities and therefore higher soil erosion resulting in an increased LS Factor. DEM sinks were filled to give the area an average value, estimated using the natural neighboring resampling technique. Both slope gradient and slope length factors were calculated and allowed the production of LS Factor grid using the following relations (Fayas et al., 2019; Thakuri et al., 2019):

$$
\mathrm{L}=\left(\frac{\lambda}{22.13}\right)^{\mathrm{m}}
$$

Where, $\mathrm{L}=$ slope length factor, $\lambda=$ slope length $(\mathrm{m}), \mathrm{m}=$ slope-length exponent

$$
\begin{gathered}
\mathrm{m}=\left(\frac{F}{1+F^{\prime}}\right) \\
\mathrm{F}=\frac{\operatorname{Sin} \beta / 0.0896}{3(\operatorname{Sin} \beta)^{0.8}+0.56^{\prime}}
\end{gathered}
$$

Where, $\mathrm{F}=$ Ratio of rill erosion to inter-rill erosion, $\beta=$ slope angle $\left(^{\circ}\right)$

In ArcMap, L was computed as follows:

$$
\mathrm{L}=\frac{\left(\text { Flow }_{A c c}+625\right)^{(m+1)}-\left(\text { Flow }_{\text {Acc }}\right)^{(m+1)}}{25^{(m+2)} * 22.13^{m}}
$$

The Slope Gradient Factor, S, was estimated as follows:

$$
\begin{gathered}
\mathrm{S}=\operatorname{Con}\left(\left(\operatorname{Tan}\left(\operatorname{Slope}^{*} 0.01745\right)<0.09\right),\left(10.8 * \operatorname{Sin}\left(\text { Slope*}^{*} 0.01745\right)+0.03\right),\right. \\
\left(16.8^{*}\left(\operatorname{Sin}\left(\text { Slope }^{*} 0.01745\right)-0.5\right)\right)
\end{gathered}
$$

Where $m$ : is a slope angle contingent variable ranging from 0.01 to 0.56 (McCool et al. 1997), and is given a value of 0.5 for the slope greater than $4.5 \%$; 0.4 on slopes of $30 \%$ to $4.5 \%$; 0.3 on slopes of $1 \%$ to $3 \%$; and 0.2 on slopes less than $1 \%$. Therefore, in this study a constant $(\mathrm{m})$ 
of 0.5 was used in Equation (5) due to the mean slope greater than $30 \%\left(15^{\circ}\right)$ observed for the study area.

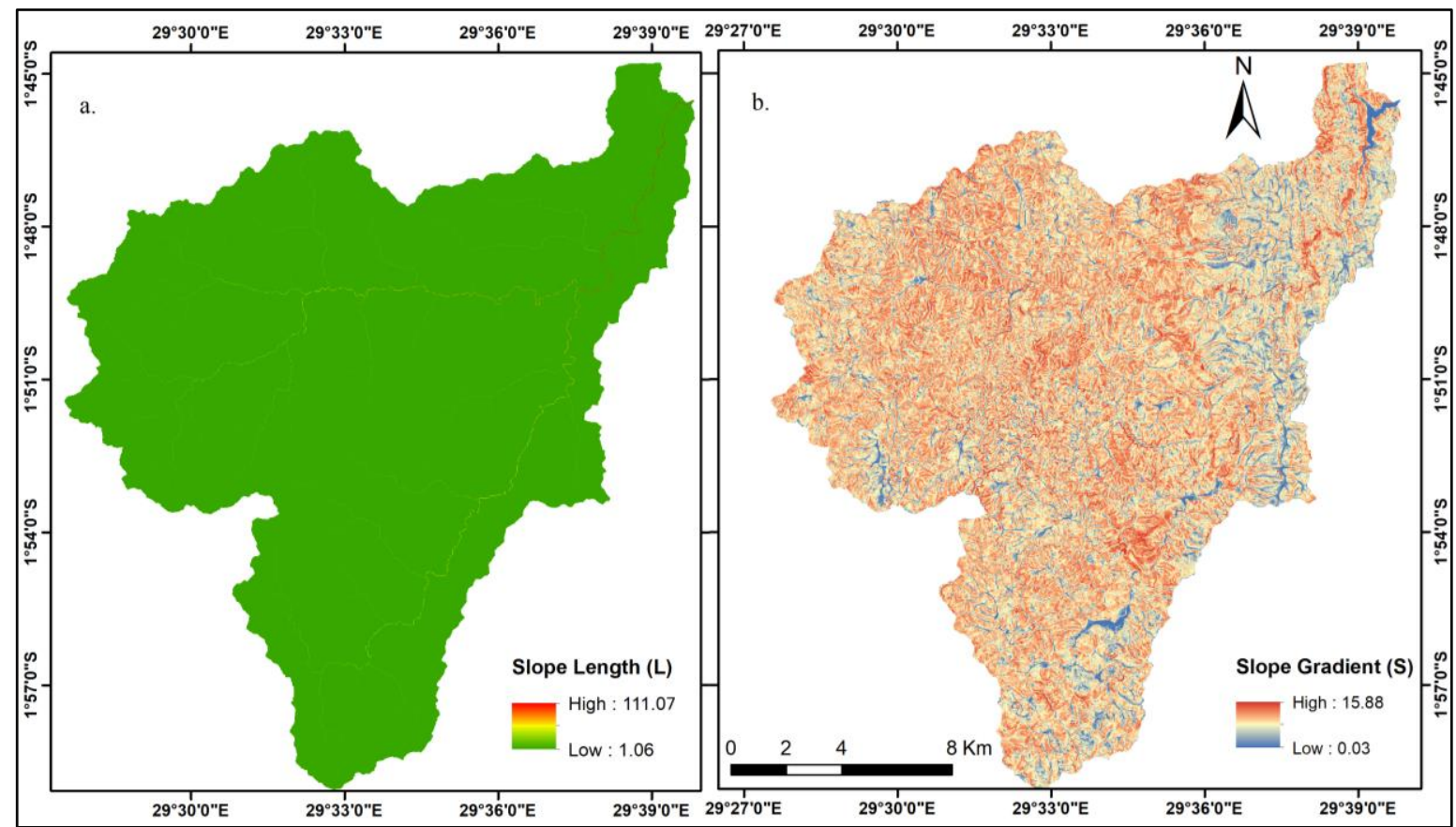

Figure 3: Slope Length Factor and Slope Gradient Factor

\section{b) Support Practice Factor $(P)$}

The Support Practice Factor "P" refers to the soil Conservation Practices implemented to alleviate soil erosion. Contour farming, terracing, and strip cropping are the commonly indexed and documented control measures (Shin, 1999). They are presented in Table 1. The P values range from 0 to 1 , where the value 0 represents a very good anthropic erosion resistance facility, and the value 1 indicates a non-anthropic resistance erosion facility.

Table 1: Support Practice Factor Values as per Soil Conservation Practice (Shin, 1999)

\begin{tabular}{lcccc}
\hline Slope \% & Strip Cropping & Contour Cropping & \multicolumn{2}{c}{ Terrace Cropping } \\
\hline & & & Bench & Broad-based \\
$0-7.0$ & 0.27 & 0.55 & 0.10 & 0.12 \\
$7.0-11.3$ & 0.30 & 0.60 & 0.10 & 0.12 \\
$11.3-17.6$ & 0.40 & 0.80 & 0.10 & 0.16 \\
$17.6-26.8$ & 0.45 & 0.90 & 0.12 & 0.18 \\
$>26.8$ & 0.50 & 1.00 & 0.14 & 0.20 \\
\hline
\end{tabular}

P Factor was produced by allocating conservation indices to corresponding reclassified slopes. Given that the study area exhibits steep slopes, where farming practices have developed following topographical changes, conservation indices used in this study are that of contour cropping.

\section{c) Rainfall Erosivity Factor (R)}

Rainfall Erosivity Factor "R" takes into account the amount of rainfall to present the peak intensity sustained over an extended period, indicating the potential ability for rainfall to cause 
soil loss (Pandit \& Isaac, 2015). Marco da Silva (2004) describes the concept of rainfall erosivity as an interaction between the kinetic energy of raindrops and the soil surface. This can result in a greater or lower degree of detachment and downslope transport of soil particles according to the amount of energy and intensity of rain by considering the same soil type, the same topographic conditions, soil cover, and management (Marco da Silva, 2004). Soil losses are therefore directly proportional to the total storm energy (E) times the maximum 30-min intensity (Pandit \& Isaac, 2015). R factor has a very significant impact on soil loss (Zhang et al., 2016). R raster map for Satinskyi catchment was produced using the daily recorded mean rainfall data from 1950 up to 2018 provided by Rwanda Meteorological Agency, which led to the final computation of $\mathrm{R}$ factor map using to the following formula (Morgan, 1985):

$$
R=38.5+0.35 P
$$

Where, $R$ represents the Rainfall Erosivity Factor, and $P$ is the Mean Annual Rainfall in mm.

\section{d) Soil Erodibility Factor (K)}

$\mathrm{K}$ Factor is referred to as the susceptibility of a soil particle type to erosion by rainfall and runoff (Williams, 2000). All fractions of the topsoil layer including sand, clay, silt, and organic carbon (Figure 4) required to estimate $\mathrm{K}$ Factor were used according to the following mathematical relations described by Williams (2000). Many researchers consider the topsoil layer to calculate $\mathrm{K}$ Factor because it is affected directly by the raindrop energy.

$$
\begin{gathered}
K_{-} \text {Factor }=f_{\text {Sand }} \cdot f_{\text {Clay }} \cdot f_{\text {OrgC }} \cdot f_{\text {Silt }} * 0.1317 \\
f_{\text {Sand }}=\left(0.2+0.3 \cdot \exp \left[-0.256 . m_{\text {Sand }} \cdot\left(1-\frac{m_{\text {Silt }}}{100}\right)\right]\right) \\
f_{\text {Clay }}=\left(\frac{m_{\text {Silt }}}{m_{\text {Clay }}+m_{\text {Silt }}}\right)^{0.3} \\
f_{\text {OrgC }}=\left(1-\frac{0.0256 . \text { OrgC }}{\text { OrgC }+\exp [3.72-2.95 . \text { OrgC }]}\right) \\
f_{\text {Silt }}=\left(1-\frac{0.7\left(1-\frac{m_{\text {Sand }}}{100}\right)}{\left(1-\frac{m_{\text {Sand }}}{100}\right)+\exp \left[-5.51+22.9 .\left(1-\frac{m_{\text {Sand }}}{100}\right)\right]}\right)
\end{gathered}
$$

Where

$m_{\text {Sand }}$ is the proportion $(\%)$ of sand content $\left(0.05-2.0 \mathrm{~mm}\right.$ diameter particles), $m_{\text {Silt }}$ is the proportion $(\%)$ of silt content $\left(0.002-0.05 \mathrm{~mm}\right.$ diameter particles), $m_{\text {Clay }}$ is the proportion (\%) of clay content $(<0.002 \mathrm{~mm}$ diameter particles), and orgc is the amount (\%) of the organic carbon content of the layer $(\%)$. 


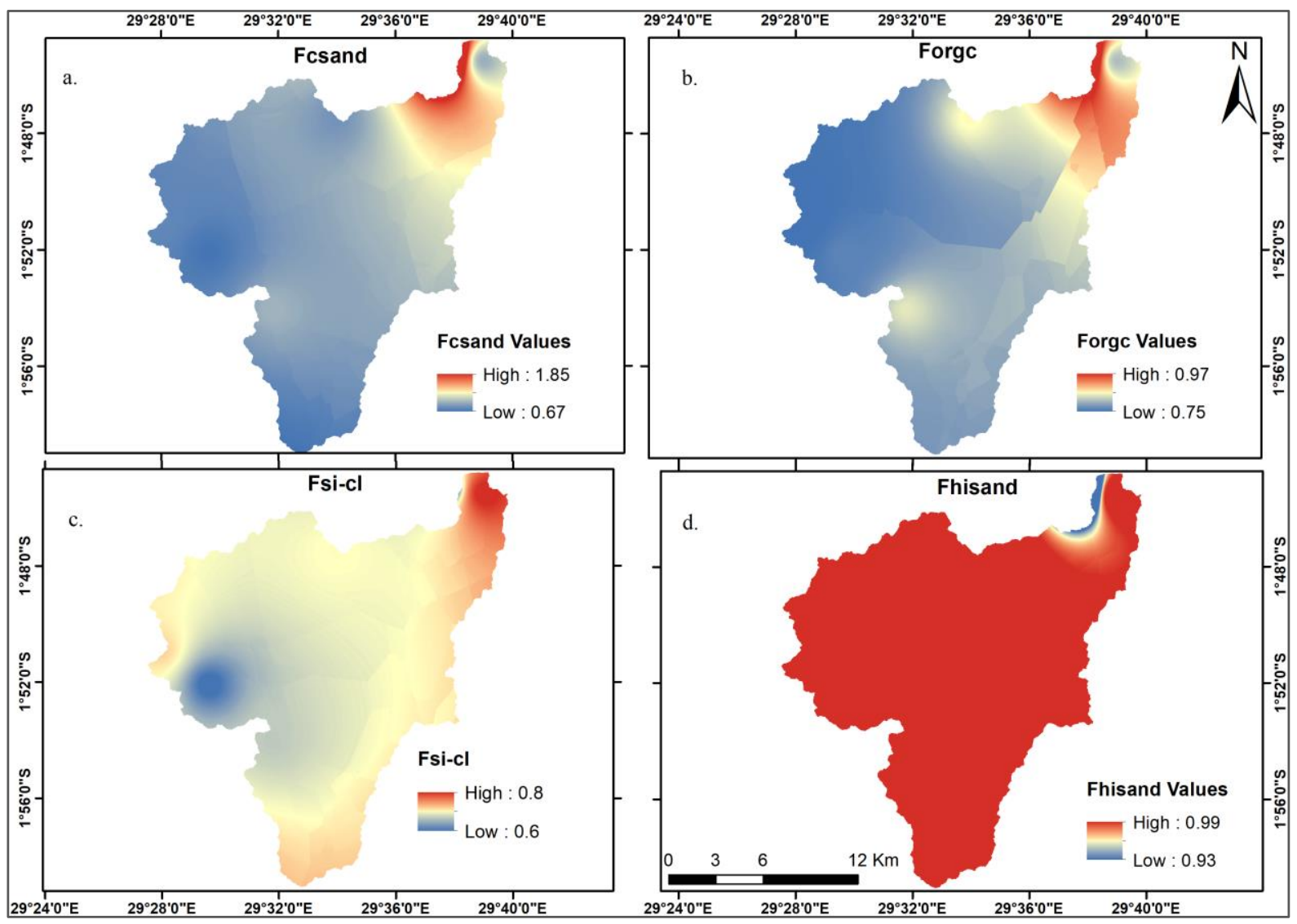

Figure 4: Soil Properties Used to Produce K Factor Map

\section{e) Land Surface Cover Management Factor (C)}

The Land Surface Cover Management Factor (C) represents the ratio of soil erosion from land cropped under specific conditions. It determines how natural vegetation or crop cover reduces rainfall energy and overflows or intercepts rainfall energy and increases infiltration. It is the second most important factor next to topography and rainfall erosivity that controls soil erosion risk (Henebry, G. M., \& Kirsten, 2004). C equals 1 under standard fallow conditions where the vegetation cover has been totally stripped off. As vegetative cover approaches $100 \%$, the $\mathrm{C}$ factor value approaches 0 . The LULC for Satinskyi Catchment was extracted from the prepared LULC of Rwanda.

The used LULC data was clipped from the current $20 \mathrm{~m}$ resolution Rwanda land cover map which dates in 2018, produced through the fusion of Landsat 8 OLI (30 m resolution) and Synthetic Aperture Radar (SAR) data (Sentinel 1) (20 m resolution) taken at regular time intervals over all seasons (time series), to gain the representativeness over the year (RWFA, 2018). Given that factors in the RUSLE model are spatially evaluated through the GIS environment, resulting in layers corresponding to individual factors reflected in the equation were overlaid and multiplied on a grid basis. Table 2 below represents $\mathrm{C}$ factor values used for land cover and land use (Thakuri et al., 2019). 
Table 2: Cover Management Factor

\begin{tabular}{lc}
\hline Land Use & C Factor \\
\hline Forest & 0.03 \\
Shrubland & 0.03 \\
Grassland & 0.01 \\
Agricultural Land & 0.21 \\
Barren Land & 0.45 \\
Built-Up & 0.00 \\
Snow Glacier & 0.00 \\
Water Body & 0.00 \\
\hline
\end{tabular}

\section{Results}

The prepared input factors for RUSLE were integrated into the ArcGIS 10.6 raster calculator for generating the soil erosion map for the study area (Figure 5f). High mean annual precipitation $(>1,300 \mathrm{~mm})$ and a generally steepened topography $\left(>26^{\circ}\right)$ constitute the major natural factors influencing high soil loss rates observed in the study area. The results showed that $\mathrm{R}$ factor value comprised between 420.2 and $579.6 \mathrm{MJ} \mathrm{mm} / \mathrm{Ha} / \mathrm{h} / \mathrm{year}$, with the highest values in the western part of the catchment and the lowest values being in the North-eastern. The Topographic Factor (LS) for the entire catchment value ranged from 0.03 to 1164.81 . The steep cultivated hillsides are separated by groove-shaped valleys and contribute significantly to sediment yields in Satinskyi catchment.

\subsection{Annual Soil Loss Rates per Slope}

The average annual soil loss in the study area was estimated at $38.4 \mathrm{t} / \mathrm{ha} /$ year (Table 3). An extensive part of the land $(91 \%)$ presents slopes exceeding $15^{\circ}$, which makes the area prone to severe soil loss estimates averaged between 31 and $41 \mathrm{t} /$ ha/year (Figure 5f). Slopes with value comprised between 15 and $30^{\circ}$ cover about $33 \%$ of the total land and are attributed to soil loss estimated at an average of $31 \mathrm{t} / \mathrm{ha} /$ year. 


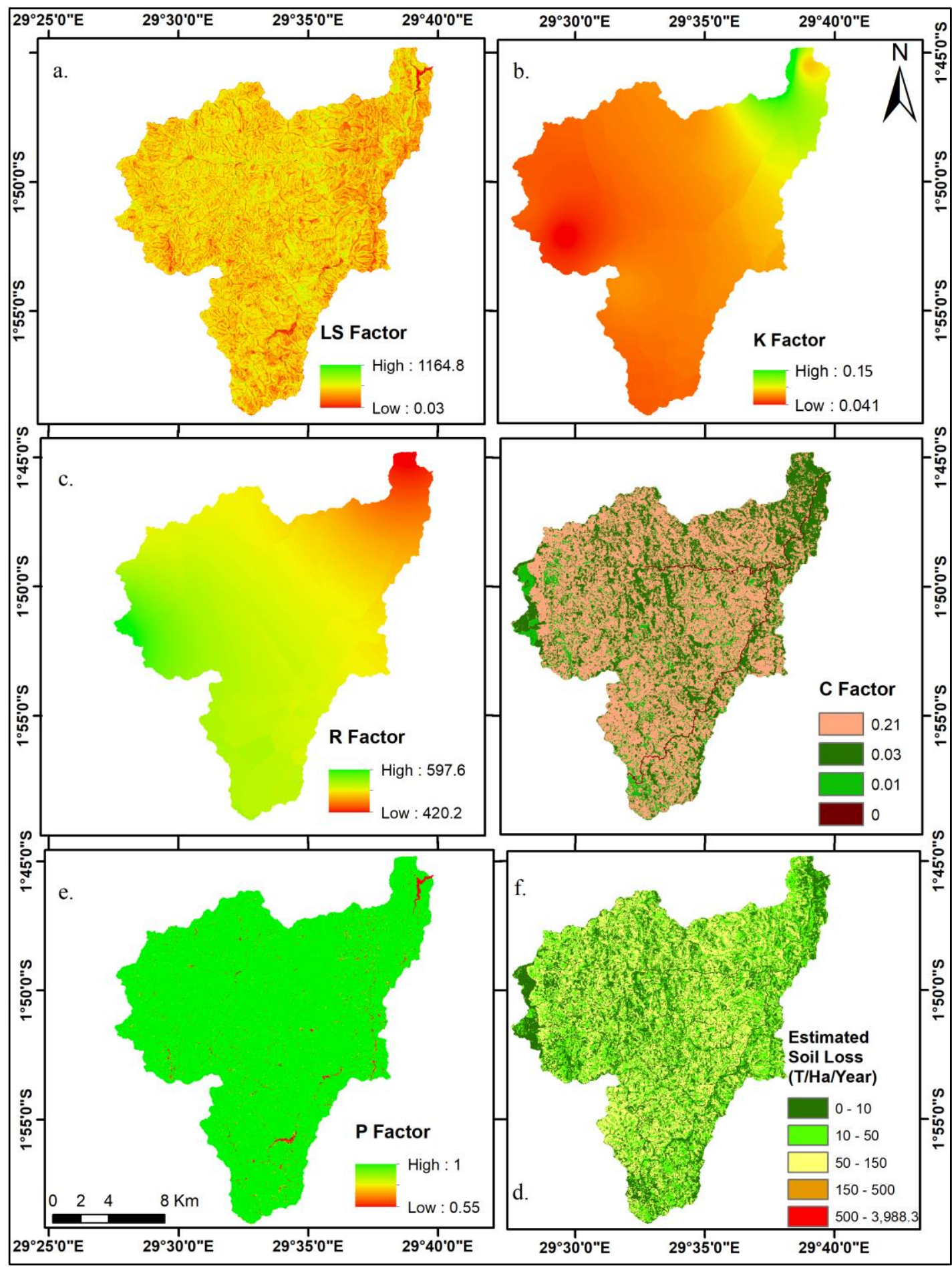

Figure 5: RUSLE Factors Maps (a, b, c, d, e) and Final Estimated Mean Annual Soil Loss (f)

Terrains with gentle slopes are limited, with only $6.6 \%$ of land having slope comprised between $7^{\circ}$ and $15^{\circ}$ with a mean annual soil loss estimated at $17.9 \mathrm{t} / \mathrm{ha} / \mathrm{year}$. The very gentle sloping lands $(0-7 \%)$ constitute about $2 \%$ of the area and present a mean soil loss estimated at $6.5 \mathrm{t} / \mathrm{ha} /$ year. 
Table 3: Annual Soil Loss Rate per Slope

\begin{tabular}{lrrrrrrr}
\hline Slope Range $\left(^{\circ}\right)$ & Area (ha) & $\begin{array}{l}\text { Percent of } \\
\text { Total Area }\end{array}$ & Min & Max & Range & Mean & Std \\
\hline $0-7$ & 619 & 2.05 & 0 & 841.5 & 841.5 & 6.5 & 17.2 \\
$7-15$ & 1,988 & 6.58 & 0 & $2,349.1$ & $2,349.1$ & 17.9 & 33.2 \\
$15-30$ & 10,109 & 33.44 & 0 & $3,988.3$ & $3,988.3$ & 30.9 & 32.2 \\
$30-77.3$ & 17,513 & 57.93 & 0 & $3,408.6$ & $3,408.6$ & 40.8 & 30.8 \\
Total & 30,229 & 100.00 & 0 & $10,587.5$ & $10,587.5$ & 96.1 & 113.4 \\
\hline
\end{tabular}

\subsection{Annual Soil Loss Rates per LULC}

The LULC has a significant impact on soil loss in the study area. The average soil loss estimates per annum in the study area (Table 4) was estimated at $13.5 \mathrm{t} / \mathrm{ha} / \mathrm{year}$, where seasonal agriculture alone which covers $60 \%$ of total land accounting for 52.7 t/ha/year.

Table 4: Mean Annual Soil Loss per Land Cover Type

\begin{tabular}{lrrrrrrr}
\hline \multicolumn{1}{c}{ LULC Class } & Area & $\begin{array}{c}\text { Percent of } \\
\text { Total Area }\end{array}$ & Min & Max & Range & Mean & Std. \\
\hline Dense Forest & 3,946 & 13.05 & 0 & 936.4 & 936.4 & 8.9 & 5.5 \\
Sparse Forest & 5,493 & 18.17 & 0 & $1,926.9$ & $1,926.9$ & 11.4 & 13.4 \\
Water & 314 & 1.04 & 0 & 0 & 0 & 0 & 0 \\
Settlements and Buildings & 10 & 0.03 & 0 & 165.1 & 165.1 & 2.4 & 10.4 \\
Agriculture (Seasonal) & 18,086 & 59.83 & 0 & $3,988.3$ & $3,988.3$ & 52.7 & 29.6 \\
Agriculture (Perennial) & 151 & 0.50 & 0 & 331.3 & 331.3 & 2.5 & 6.5 \\
Open Areas or grass & 2,229 & 7.37 & 0 & 870.5 & 870.5 & 3.1 & 7.3 \\
Total & $\mathbf{3 0 , 2 2 9}$ & $\mathbf{1 0 0 . 0 0}$ & $\mathbf{0}$ & $\mathbf{1 0 , 0 4 0 . 7}$ & $\mathbf{1 0 , 0 4 0 . 7}$ & $\mathbf{8 2 . 2}$ & $\mathbf{8 6 . 9}$ \\
\hline
\end{tabular}

Soil loss rates decrease with an increased vegetative cover. Under sparse forest (18\% of total land) soil loss is estimated at $11.4 \mathrm{t} / \mathrm{ha} /$ year, whereas on vegetated hill slopes ( $13 \%$ of the total land) soil loss rate accounts for $8.9 \mathrm{t} / \mathrm{ha} /$ year.

\section{Discussion}

Soil loss estimation as presented in table 3 and 4, and illustrated by Figure 6, indicates some values which far exceed the soil loss tolerance ( $\mathrm{T}$-value). The $\mathrm{T}$-value represents a maximum rate of soil erosion that can occur and still permits crop productivity to be sustained economically (Renard et al., 1997). Chinese standard for classification and gradation of soil erosion (Yang, et al. 2013) has set an annual T-value comprised between 5 and 10 t/ha/year. In the USDA-NRCS manual, $\mathrm{T}$ was set at 10. Though the T threshold value is not defined yet for individual regions in Rwanda, the soil loss potential in the study area (38 t/ha/year) far exceeds the T 10 value recommended by the USDA-NRCS manual (Liu et al, 2012).

The findings were correlated with similar studies carried out in Rwanda and different parts of the world and rates of soil erosion are alike. Lewis et al. (1988) found that in Rwanda, seasonal soil losses ranged from $1 \mathrm{t} / \mathrm{ha} /$ year to $143 \mathrm{t} / \mathrm{ha} /$ year. The highest values of estimated mean annual soil loss per LULC has been attributed to seasonal agricultural land, which is in 
agreement with the statement by the previous studies, such as Mugabowindekwe and Rwanyiziri (2020), indicating that the agricultural land is the most frequently disturbed land use in Rwanda. Nevertheless, the range of average seasonal soil loss in Rwanda showed a pattern of local differences that closely followed variations in rainfall and topography.

The study of He et al. (2020) on Rwanda showed average annual soil losses comprised between $48.6 \mathrm{t} / \mathrm{ha} /$ year and $39.2 \mathrm{t} / \mathrm{ha} /$ year in 2000 and 2015 respectively. Findings of Shao et al. (2016) indicated that the Lake Kivu basin is exposed to soil erosion risk with a mean annual rate of $30 \mathrm{t} / \mathrm{ha} / \mathrm{year}$ and only $33 \%$ of the total non-water area is associated with a tolerable soil loss ( $\leq 10 \mathrm{t} / \mathrm{ha} /$ year). Byizigiro (2016) has found a slightly small soil erosion rate in the Gatumba sector (27 t/ha/year). In Nepal, Thakuri et al. (2019) found different rates of mean soil erosion under different topographies and land uses. Soil erosion based on the physiographic region of the country shows that the highlands of Nepal have mean erosion rates comprised between 38 , and $28 \mathrm{t} / \mathrm{ha} /$ year. The same conclusion was made for the mean annual soil losses varying following the changing topographies, rainfall, and land use types.

Though the estimated soil loss in Satinskyi catchment is in the same order of magnitude of the findings mentioned above, it is, however, important to highlight other values, which show elevated soil loss ranges. The research of Zhang et al. (2016) on erosion over entire Rwanda showed that the mean soil erosion rate was $250 \mathrm{t} / \mathrm{ha} /$ year, whereas the mean soil erosion rate over cropland, which occupied $56 \%$ of the national land area, was estimated at $421 \mathrm{t} / \mathrm{ha} / \mathrm{year}$, and the current suitable cultivated land presents a mean soil erosion of $27 \mathrm{t} / \mathrm{ha} / \mathrm{year}$, contributing to the total annual soil loss by $4.87 \%$ countrywide.

Previous studies attempted to classify the soil loss rates in a numerical severity ranges with the purpose of planning and allocating appropriate remedial strategies, but ranges suggested are not uniform due to priority intervention (Thakuri, 2019; Rahaman et al., 2015; Kevers et al., 1955). Slopes of the study area have been reclassified after Kevers et al (1955) to identify how much land within a given slope class deserves allocation of particular management practices (Table 5).

Table 5: Manageability of the Satinskyi Catchment basing on Slope Classes

\begin{tabular}{rrlrrrr}
\hline \multicolumn{1}{c}{$\begin{array}{c}\text { Slope } \\
\text { Range }\left(^{\circ}\right)\end{array}$} & $\begin{array}{c}\text { Slope Range } \\
(\%)\end{array}$ & Slope Class & \multicolumn{1}{l}{$\begin{array}{l}\text { Area } \\
\text { (ha) }\end{array}$} & $\begin{array}{l}\text { Percent of } \\
\text { Total Area }\end{array}$ & $\begin{array}{l}\text { Mean Annual } \\
\text { Soil Loss (tone) }\end{array}$ & $\begin{array}{r}\text { Total Soil } \\
\text { Loss (\%) }\end{array}$ \\
\hline $0-2$ & $0-5$ & Class I & 121.2 & 0.4 & 1.5 & 0.02 \\
$2-7$ & $5-12$ & Class II & 498.0 & 1.6 & 7.8 & 0.36 \\
$7-15$ & $12-25$ & Class III & $1,988.7$ & 6.6 & 17.9 & 3.34 \\
$15-35$ & $25-45$ & Class IV & $15,999.0$ & 52.9 & 33.7 & 50.52 \\
$>35$ & $>45$ & Class V & $11,623.8$ & 38.5 & 42.0 & 45.76 \\
Total & & & $\mathbf{3 0 , 2 3 0 . 7}$ & $\mathbf{1 0 0}$ & & $\mathbf{1 0 0}$ \\
\hline
\end{tabular}

According to Kevers' classification, slopes between $0-2^{\circ}(0-5 \%)$ correspond to Class I. Soils of this class are not degraded and don't require soil erosion control practices. The soil productivity of land is taken as normal. Class II $2-7^{\circ}(5-12 \%)$ terrain has normal productivity but needs minor correction to control soil erosion. Within Class III 7-15 ${ }^{\circ}$ (12-25\%) lands 
present normal productivity but require major correction to control soil erosion (terrain relatively highly degraded). As can be seen, slope classes $\boldsymbol{I}, \boldsymbol{I I}$, and $\boldsymbol{I I I}$ cover only $3.72 \%$ of total land. The remainder of the terrain (96.28\% of total land) is classified within slope classes IV $\left(15-35^{\circ}\right)$ and V $\left(>35^{\circ}\right)$. Class IV 15-35 (25-45\%) represents lands with poor productivity either because of the thin arable soil layer or soil is highly degraded. Beyond the slope of the $\boldsymbol{V}$, the terrain has to be abandoned from all farming purposes.

Based on their results, previous studies including Rahaman et al. (2015), Thakuri (2019), Kevers et al (1955) among others, attempted to classify soil erosion into soil erosion severity map, to which we referred to classify results for our study area with seven classes summarized in table 6 and illustrated by Figure 6 .

Table 6: Estimated Soil Loss per Severity Class

\begin{tabular}{rccrrrr}
\hline $\begin{array}{c}\text { Soil Loss } \\
\text { (ton/ha/year) }\end{array}$ & Severity Class & $\begin{array}{c}\text { Priority } \\
\text { Class }\end{array}$ & Area (ha) & $\begin{array}{c}\text { Percent of } \\
\text { Total Area } \\
(\%)\end{array}$ & $\begin{array}{c}\text { Mean Annual } \\
\text { Soil Loss (ton) }\end{array}$ & $\begin{array}{c}\text { Percent of } \\
\text { Total Soil } \\
\text { Loss }\end{array}$ \\
\hline $0-10$ & Low & VII & $9,844.9$ & 32.6 & 5.9 & 5.4 \\
$10-20$ & Moderate & VI & $3,241.9$ & 10.7 & 12.5 & 3.8 \\
$20-30$ & High & V & 987.3 & 3.3 & 25.4 & 2.4 \\
$30-45$ & Very High & IV & $3,197.1$ & 10.6 & 38.5 & 11.5 \\
$45-60$ & Severe & III & $6,294.2$ & 20.8 & 53.1 & 31.3 \\
$60-80$ & Very Severe & II & $5,768.9$ & 19.1 & 67.3 & 36.4 \\
$>80$ & Extremely & I & 896.4 & 3.0 & 108.5 & 9.1 \\
& Severe & & & & & \\
Total & & & $\mathbf{3 0 , 2 3 0 . 7}$ & & & \\
\hline
\end{tabular}

The soil loss severity per slope class manageability was estimated at low ( $<10 \mathrm{t} / \mathrm{ha} / \mathrm{year})$, moderate (10-20 t/ha/year), high (20-30 t/ha/year), very high (30-45 t/ha/year), severe (45-60 t/ha/year), very severe (60-80 t/ha/year) and extremely severe (> $80 \mathrm{t} / \mathrm{ha} /$ year). Referring to Kevers' classification of slopes described above, it appears that $96.28 \%$ of the total land of the study area is difficult to manage. On that basis, it was possible to establish the relation between ranges soil loss rates per annum and severity which serves as guidelines to the allocation of remediation measures.

Considering the distribution of mean annual soil loss on the study area, $67.5 \%$ of the total land record annual soil loss exceeding $10 \mathrm{t} / \mathrm{ha} /$ year, with $58 \%$ of land (from class I to class Iv) recording mean annual soil loss greater than $30 \mathrm{t} / \mathrm{ha} / \mathrm{year} .96 .58 \%$ of the total land has a slope exceeding $7^{\circ}$ with soil loss estimates of more than $17.9 \mathrm{t} / \mathrm{ha} / \mathrm{year}$, which is a serious threat to the sustainability of the local population depending on agriculture in the study area. Considering the land-use practices, seasonal agriculture alone which covers $60 \%$ of total land accounts for $52.7 \mathrm{t} /$ ha/year of soil loss estimates. The identified highest soil loss rates (> 80 t/ha/year) could be associated with localized mining pits or barren land in the study area. 


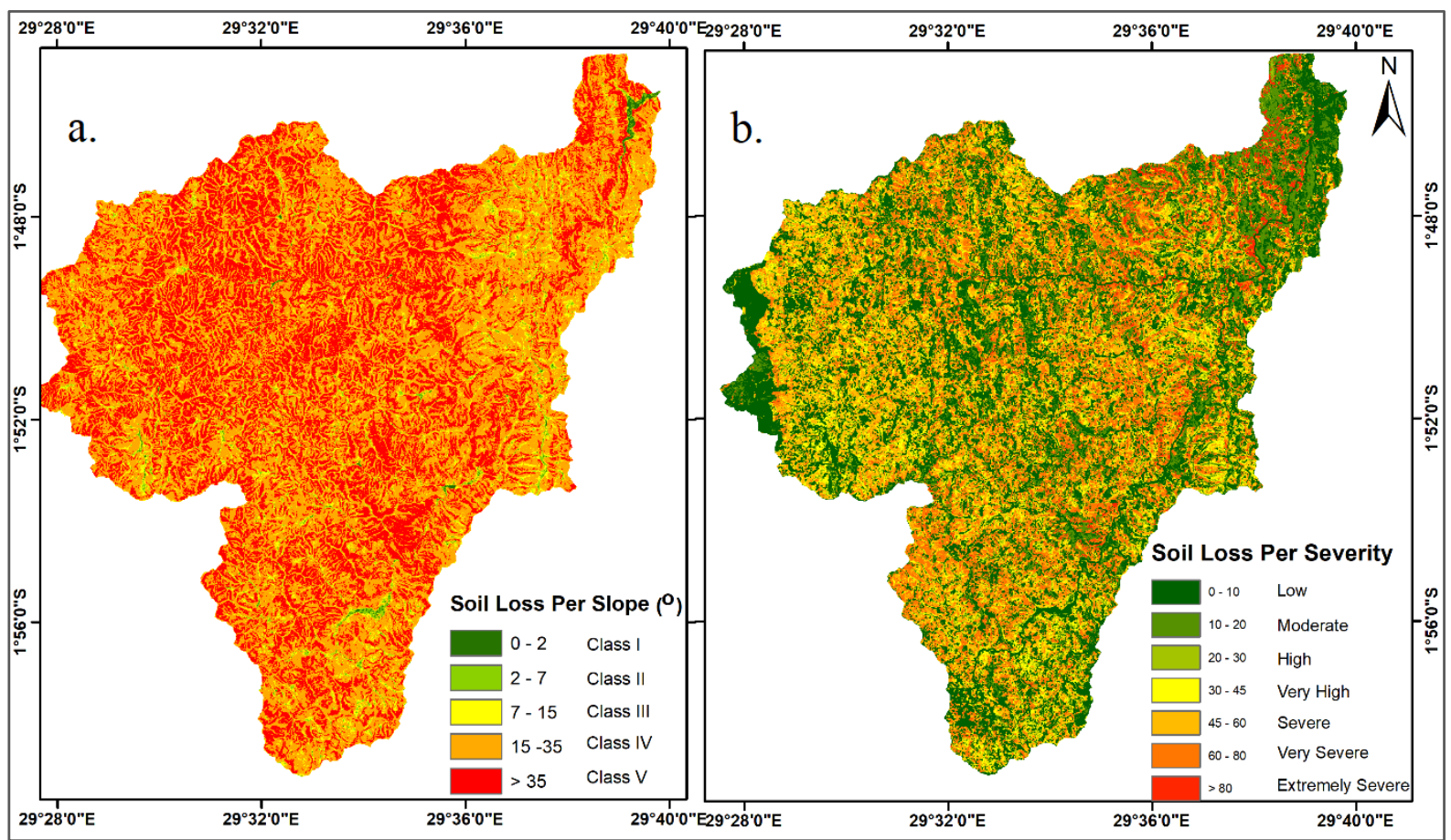

Figure 6: Annual Mean Soil Loss per Slope (a) and Soil Loss Severity classes (b)

The adverse effects of soil erosion in the study area might have many ramifications. As the maximum tolerable soil loss for cultivated slopes is well known $(\leq 10 \mathrm{t} / \mathrm{ha} / \mathrm{year})$, it is obvious that crop production will keep on suffering strongly the greatest ecological damage through soil degradation processes threatening food security, given the high soil erosion rates (Hans, 1983). Many scientific discourses including Ashras and Issaka (2017) highlighted the on-site and off-site adverse effects of soil erosion on flora, fauna, soil productivity, open water bodies, wetlands, and dam operability. In such conditions, natural processes of soil erosion and earth material under the control of numbers of natural factors including substratum, slope, climate and vegetation already severe by nature are likely to be triggered by among others anthropogenic activities, ploughing, mining, and construction (Byizigiro et al. 2020).

In countries with an increasing population such as Rwanda, where there is a high demand for land for agricultural production and construction, soil erosion is a major problem. Poor land management may result in water runoff across landscape instead of adequate infiltration. Relocated topsoil which is rich in organic matter and nutrients may build up over time or is transported off-site where it accumulates in drainage channels and is usually severe on unprotected sloppy areas (Ashras and Issaka, 2017). Reduction of soil water holding capacity (WHC) and infiltration with an increasing overland flow reflect the level of soil degradation. The absence of reduced fallow periods, however, contributes to accelerated soil degradation. In almost all developing countries with similar land-use patterns, intensive soil erosion deprives plants and animals of their natural habitat with increasing pollution of air and siltation of open water bodies including dams (Berkun, 2010). Pollution of nearby water bodies and wetlands and the reduction in cropland productivity is linked to the erosion process. Though our study on Satinskyi catchment was bounded to estimating soil erosion, this research establishes a starting point for a further in-depth investigation of the negative impacts of soil erosion in the studied area. 


\section{Conclusion}

Soil erosion is a national concern in Rwanda in general, particularly in the highly elevated and mountainous areas of the Northern and Western parts of Rwanda where Satinskyi catchment is located. In this area, steep slopes (greater than $>15^{\circ}$ ) characterize more than $91 \%$ of the land. The catchment also accounts for high population density with 491 inhabitants $/ \mathrm{km}^{2}$, of whom the majority rely on agricultural activities. Steepened topography and intensive land-use/landcover changes, in addition to high rainfall patterns, constitute, among others, major natural and anthropogenic factors triggering and aggravating soil loss rates characterizing the area. For average values of soil loss rate of $13.5 \mathrm{t} / \mathrm{ha} /$ year taking into consideration the effect of land cover and land use and 38,4 t/ha/year considering the mean slope $\left(26^{\circ}\right)$, Satinskyi catchment is classified as experiencing severe and very severe soil erosion rates. The highest soil erosion rates were identified in barren and highly disturbed lands, especially for land under seasonal agriculture.

Given that extensive part of Satinskyi catchment presents steeps slopes and thus, prone to soil high soil loss rates, knowledge of processes involved in soil erosion and their importance are essential for recommending appropriate mitigation measures. Outcomes of the studies will serve as a guide on whether terraces are the most recommendable or if supplementary measures have to be suggested to protect soil against erosion. The later should be agronomic measures of soil conservation such as mulching, agroforestry, etc., which would significantly contribute to alleviating devastating soil erosion processes.

\section{Acknowledgment}

Authors would like to thank the Centre for Geographical Information System and Remote Sensing of Rwanda (CGIS-RS) for providing spatial data required for soil loss estimates computation, and the anonymous reviewers for their valuable comments that enabled to improve the manuscript.

\section{References}

Ashras, A. M., \& Issaka, S. (2017). Impact of Soil Erosion and Degradation on Water Quality: A Review. Geology, Ecology, and Landscapes, Vol. 1 (1) 2017: 1-11.

Bayramin, I., Erpul, G., \& Erdogan, H.E. (2006). Use of CORINE Methodology to Assess Soil Erosion Risk in the Semi-Arid Area of Beypazari, Ankara, Turkey. Journal of Agriculture and Forestry, 30, 81-100.

Berkun, M. (2010). Hydroelectric Potential and Environmental Effects of Multi-Dam Hydropower Projects in Turkey. Energy for Sustainable Development, 14 (2010) 320329.

Byizigiro, R. V. (2016). Geomorphic Processes associated with Small-scale Opencast Mining and Mitigation Measures: Case Study of the Gatumba Mining District in the Western Highlands of Rwanda (unpublished). Cottbus: BTU-CS Digitales Repositorium. 
Byizigiro, R. V., Biryabarema, M., \& Rwanyiziri, G. (2020). Alleviating some Environmental Impacts Resulting from Artisanal and Small-scale Mining: A Critical Review. RJESTEAfrica Journal Online, Vol. 3 No 1 (2020): 1-19.

Byizigiro, R. V., Raab, T., \& Maurer, T. (2015). Small-Scale Opencast Mining: An Important Research Field for Anthropogenic Geomorphology. DIE ERDE, 146 (4): 213-231.

Cendrero, A., \& Panizza, M. (1997). Geomorphology and Environmental Impact Assessment: An Introduction. Suppl. Geogr. Fis. Dinam. Quat. III, T., 167-172.

Diodato, N., Bellocchi, G., Romano, N., \& Chirico, G. B. (2011). How the aggressiveness of rainfalls in the Mediterranean lands is enhanced by climate change. Climate Change,, 108(3), 591-599.

Favis-Mortlock, A., Boardman, J., \& MacMillan, V. (2001). The Limits of Erosion Modeling: Why We Should Proceed with Care. In R. S. Harmon, \& W. W. Doe III, Landscape Erosion and Evolution Modeling (S. 477-516). Boston: Springer.

Fayas, C. S. (2019). Soil Loss Estimation Using RUSLEModel to Prioritize Erosion Control in KELANI River Basin in Sri Lanka". International Soil and Water Conservation Research, Vol 7:2 130-137.

Flanagan, D. C., Ascough II, J. C., Nearing, M. A., \& Laflen, J. M. (2001). The Water Erosion Prediction Project (WEPP) Model. In R. S. Harmon, \& W. W. DoeIII, Landscape Erosion and Evolution Modeling (S. 145-199). Boston: Springer.

Ngororero District (2013). District Development Plan: 2013 - 2018. Kigali: Ministry of Good Governance.

Grey, O., Setegn, S., \& Webber, G. F. (2014). Application of the Soil and Water Assessment Tool (SWAT Model) on a small tropical island (Great River Watershed, Jamaica) as a tool in Integrated Watershed and Coastal Zone Management. Revista de Biologia Tropical, 62(3):291-305.

Gurebiyaw, K., Yigzaw, M., \& Kindie, A. (2018). Analysis of Fundamental Drivers of Soil Resource Degradation Phenomenon. Journal of Academia and Industrial Research, Vol. 7 (4).

He, X., Nambajimana, J. D., Zhou, J., Justine, M. F., Li, J., Khurram, D., et al. (2020). Land Use Change Impacts on Water Erosion in Rwanda. Sustainability, 12 (50). DOI:10.3390/su12010050, 1-23.

Hurni, H. (1983). Soil Erosion and Soil Formation in Agricultural Ecosystems: Ethiopia and Northern Thailand. Mountain Research and Development, Vol. 3 (2):131.

Karamage, F., Zhang, C., Ndayisaba, F., Shao, H., Kayiranga, A., Fang, X., et al. (2016). Extent of Cropland and Related Soil Erosion Risk in Rwanda. Sustainability, 8 (609), pp. 1-19. DOI:10.3390/su8070609 . 
Kevers, G. \&. (1955). Les cartes d' utilization des sols dans l'est du Congo Belge. Belgique Ministere des Colonies. B. Agicult. du Congo Belge, 24 K83. 46: 1361-1386.

Lewis, L. A. (1988). Soil loss, agriculture, and conservation in Rwanda: Toward sound strategies for soil management. Journal of Soil and Water Conservation, 43 (5): 418-421.

Liu, Y., Gao, G., Fu, B., Wang, S., \& Zhou, J. (2012). Coupling the modified SCS-CN and RUSLE models to simulate hydrological effects of restoring vegetation in the Loess Plateau of China. Hydrol. Earth Syst. Sci, 16, 2347-2364.

Lo, A., El-Swaify, S., \& Dangler, E. \&. (2016). Effectiveness of EI 30 as an Erosivity Index in Hawaii. fao, Available online: http://agris.fao.org/agr is search/search.do?recordID=US8639059.

Marco da Silva, A. (2004). Rainfall Erosivity map for Brazil. Catena, 57: 251 - 259.

Merritt, W., \& Letcher, R. \&. (2003). A review of erosion and sediment transport models. Environmental Modelling \& Software, 8 (2003) 761-799.

MINALOC. (2013). 1Ngororeo District Development Plan (2013 - 2018), Western Province, Rwanda. Kigali: Ministry of Good Governance.

MINICOFIN. (2015). Fourth Population and Housing Census, Ngororero District, Rwanda. Kigali: National Institute of Statistics of Rwanda.

Montgomery, D. (2007). Soil erosion and agricultural sustainability. Sustainability Science PNAS, 104(33): 13268-13272. DOI: 10.1073/pnas.0611508104.

Morgan, R. P. (2005). Soil Erosion and Conservation (3rd ed). Oxford: Blackwell Publishing.

Morgan, R. P., Quinton, J. N., Smith, R. E., Govers, G., Poesen, J. W., Auerswald, K., et al. (1998). The European Soil Erosion Model (EUROSEM): a dynamic approach for predicting sediment transport from fields and small catchments. In S. N. Lane, Earth Surface Processes and Landforms (S. 527-544). Lausanne: John Wiley \& Sons.

Morgan, R., \& Morgan, D. (1984). A predictive model for the assessment of soil erosion risk. J. Agric. Eng. Res., 30, 245-253.

Mugabowindekwe, M. \& Rwanyiziri, G. (2020). Comparative Assessment of Homogeneity Differences in Multi-Temporal NDVI Strata and the Currently Used Agricultural Area Frames in Rwanda. South African Journal of Geomatics, 9 (1), 89-107

Nyesheja, E.M., Chen, X., El-Tantawi, A.M., Karamage, F., Mupenzi, C., \& Nsengiyumva, J.B. (2019). Soil Erosion Assessment using RUSLE model in the Congo Nile Ridge region of Rwanda. Physical Geography, 40 (4), 339-360.

Onori, F., De Bonis, P., \& Grauso, S. (2006). Soil erosion prediction at the basin scale using the revised universal soil loss equation (RUSLE) in a catchment of Sicily (southern Italy). Environmental Geology, pp. 50, 1129-1140. 
Pandit, V., \& Isaac, K. (2015). A Scenario of Rainfall Erosivity Index Research. International Journal of Engineering Research, Vol.4: 12, pp: 668-672.

Pohl, W., Rukazambuga, D., \& Biryabarema, M. (2009). Sustainable restitution/recultivation of artisanal tantalum mning wastland in central Africa. Butare : Etudes Rwandaises .

Prasannakumar, V., Vijith, H., H., Abinod, S., \& Geetha, N. (2012). Estimation of soil erosion risk within a small mountainous sub-watershed in Kerala, India, using Revised Universal Soil Loss Equation (RUSLE) and Geo-informatics technology. Geoscience Frontiers, S. 3(2), 209-215.

Rahaman, S. A., Aruchamy, S., \& Jegankumar, R. \&. (2015). Estimation of Annual Average Soil Loss, based on RUSLE Model in Kallar Watershed, Bhavani Basin, Tamil Nadu, India. DOI:10.5194/isprsannals-II-2-W2-207-2015. Joint International Geoinformation Conference 2015, 28-30 October 2015 (S. 207-2014). Kuala Lumpu: ISPRS Annals of Photogrammetry, Remote Sensing and Spatial Information Sciences, Volume II-2/W2, 2015.

REMA. (2015). State of Environment and Outlook Report 2015. Kigali: Rwanda Environment Management Authority.

Renard, K. J., \& Freimund, J. R. (1994). Using monthly precipitation data to estimate the Rfactor in the revised USLE. Journal of Hydrology, pp. 157, 287-306.

Renard, K., Foster, G., Weesies, G., McCool, D., \& Yoder, D. (1997). Predicting Soil Erosion by Water: A Guide to Conservation Planning with the Revised Universal Soil Loss Equation. Volume 703. Washington, DC, USA: United States Department of Agriculture.

Renschler, C. S., Mannaerts, C., \& Diekkruger, B. (1999). Evaluating spatial and temporal variability in soil erosion risk - rainfall Erosivity and soil loss ratios in Andalusia, Spain. Catena, pp. 34, 209-225.

RoR. (2018). Rwanda Agriculture Policy. Kigali: Republic of Rwanda.

Rose, C., Coughlan, K., \& Fentie, B. (1998). Griffith University Erosion System Template (GUEST). In J. Boardman, \& D. Favis-Mortlock, Modelling Soil Erosion by Water. NATO ASI Series (Series I: Global Environmental Change), vol 55 (S. 399-412). Berlin, Heidelberg: Springer.

Rwanda, M. (2018). National Environment and Climate Change Policy. Kigali: Ministry of Environment.

Rwanyiziri, G., Uwiragiye, A., Tuyishimire, J., Mugabowindekwe, M., Mutabazi, A., Hategekimana, S., et al. (2019). Assessing the Impact of Climate Change and Variability on Wetland Maize Production and the Implication on Food Security in the Highlands and Central Plateaus of Rwanda. Ghana Journal of Geography, 11(2): 77-102. 
RWFA. (2018). Land Use - Land Cover Map for Rwanda. Kigali: Rwanda Water and Forestry Authority.

Setegn, S. G., Srinivasan, R., Dargahi, B., \& Melesse, A. M. (2009). Spatial delineation of soil erosion vulnerability in the Lake Tana Basin, Ethiopia. Hydrological Processes, DOI: 10.1002/hyp.7476.

Shao, H., Karamage, F., Chen, X., Ndayisaba, F, Nahayo, L., et al. (2016). Deforestation Effects on Soil Erosion in the Lake Kivu Basin, D.R. Congo-Rwanda. Forests, 7 (281): $1-17$.

Shiferaw, A. (2011). Estimating soil loss rates for soil conservation planning in the Borena Woreda of South Wollo Highlands, Ethiopia. Journal of Sustainable Development in Africa, S. 13(3), 87-106.

Shin, G. (1999). The Analysis of Soil Erosion Analysis in Watershed Using GIS. Ph.D. Thesis. Chuncheon: Kangwon National UniversitySouth Korea.

Thakuri, S., Koirala, P., Sudeep * Joshi, S., \& Chauhan, R. (2019). Estimation of Soil Erosion in Nepal Using a RUSLE Modeling and Geospatial Tool. Geosciences, 9, 147; DOI:10.3390/geosciences9040147.

Vågen, T. G., Winowiecki, A. L., Tmene, D., \& Tondoh, E. J. (2013). The Land Degradation Surveillance Framework (LDSF). Nairobi: World Agroforestry Centre.

WCS. (2019). Vital Signs' Data Analysis for Ecosystem Management and Climate Resilient Agricultural System towards Environmental Sustainability in Rwanda. Kigali: Wildlife Conservation Society.

Williams J.R., N. S. (2000). Erosion Soil and Water Assessment Tool Theoretical Documentation. pp. 625. Texas: Agricultural Experiment Station.

Wischmeier, W. H., \& Smith, D. D. (1978). Predicting rainfall-erosion loss: A guide to conservation planning. Agricultural Handbook No. 537. New York: U.S Department of Agriculture.

Yang, Q., Zhang, H., Li, R., Liu, Q., Moore, D., He, P., et al. (2013). Extension of a GIS procedure for calculating the RUSLE equation LS factor. Computer and Geosciences, pp. 52, 177-188.

Zhang, C., Karamage, F., Ndayisaba, F., Shao, H., Kayiranga, A., Fang, X., et al. (2016). Extent of Cropland and Related Soil Erosion Risk in Rwanda. Sustainability, 8 (609).

Zhao, L., \& Hou, R. (2019). Human causes of soil loss in rural karst environments: a case study of Guizhou, China. Scientific Report, 9: 3225 (2019). 